\title{
Research on English Teaching Integration into Chinese Excellent Traditional Culture under the Background of "Belt and Road"
}

\author{
Xiuli Gou ${ }^{1, ~ a}$, Hui Li ${ }^{2, b}$, Jiarong Hao ${ }^{3, c}$, Peng Zhang ${ }^{1, d}$ \\ ${ }^{1}$ College of Foreign Languages, Bohai University, Jinzhou, 121013, China \\ ${ }^{2}$ Teaching and Research Institute of Foreign Languages, Bohai University, Jinzhou, 121013, China \\ ${ }^{3}$ College of Public Foreign Languages, Jinzhou Medical University, Jinzhou, 121001, China \\ a1029915835@qq.com, bnancylh@126.com, '871122594@qq.com, dzhangpeng444444@126.com
}

Keywords: "Belt and Road"; English teaching; integration; Chinese excellent traditional culture; countermeasures

\begin{abstract}
The ultimate success of the "Belt and Road" strategic conception requires the infiltration and promotion of cultural exchanges. This paper clarifies the status quo of English teaching in Chinese excellent traditional culture, analyzes the reasons for the lack of Chinese excellent traditional culture in English teaching, and puts forward the countermeasures of English teaching into Chinese excellent traditional culture under the background of "Belt and Road". The specific countermeasures include: let students feel the charm of China's excellent traditional culture, let students fully understand the importance of the "Belt and Road" construction culture, cultivate students' correct Chinese and foreign cultural values, cultivate students' intercultural communication ability, and integrate excellent traditional culture into English teaching content system, and integrate Chinese excellent traditional culture into English reading teaching.
\end{abstract}

\section{Introduction}

The "One Belt And One Road" strategy is the major decision for China to further integrate into the world economic system and strengthen economic, trade and cultural cooperation with neighboring countries. It is also the major decision to influence and optimize the order and structure of world economic and social development. The conception of "One Belt And One Road" not only strengthens cultural exchanges and mutual advancement along the countries in the line, enhances complementarities, and enables Eastern culture to be transmitted the wide international world, enabling countries along the line to achieve the common understanding of unity and common development through cultural exchange platforms. As the spiritual bond of each side contacting strategy, culture has flexible affinity and more rigid penetration. The development of the community of destiny needs to strengthen cultural exchanges. The ultimate success of the "One Belt And One Road" strategic conception requires the infiltration and promotion of cultural exchange.

The "One Belt And One Road" strategy has made the economic and trade cooperation and exchanges of all countries in the world more and more frequent. English plays an important role as a carrier of language communication. It also puts forward new requirements for the cultivation of English talents: English talents must constantly improve their intercultural communication skills and be able to accurately grasp the language connotation, scientifically mastery the language communication skills, flexibly use language skills, which can effectively resolve the communication crisis, vigorously promote the achievement of cooperation intention, and obtain ideal economic benefits. The improvement of intercultural communication ability is inseparable from the edification of Chinese excellent traditional culture. English teachers who are the main of English teaching should use English teaching as the basic carrier, focus on integrating Chinese excellent traditional culture, and seek breakthroughs in path exploration, in practicality and effectiveness. Practicability, effectiveness and other aspects continue to develop, find more 
matching points in the path of English teaching and traditional culture integration, and better serve the "One Belt And One Road" construction.

\section{2. "Belt and Road" Construction and Chinese Excellent Traditional Culture}

Culture is the soul of the "One Belt And One Road". To successfully implement the "One Belt And One Road" strategy, we must adhere to the principle of culture and establish the high degree of consciousness that culture leads the economy. We should not only play the role of promoting modern culture, but also integrate Chinese excellent traditional culture into the "One Belt And One Road" building, strive to promote the inheritance and innovation of China's excellent traditional culture, deepen exchanges and cooperation with countries along the line, and thus achieve common development.

China's excellent traditional culture promotes the construction of the "One Belt And One Road". The construction of "One Belt And One Road" is inseparable from the support and promotion of culture, and advocates the conception of "co-industry, co-construction, co-share, co-win, cooperation, balance, and universal benefit" and upholds "peaceful development, openness and inclusiveness each other, benefit and win each other". The cultural value of it is closely linked to the pursuit of the basic values of Chinese traditional culture. Adhere to "combination with the same method" and promote the peaceful coexistence of all countries. Under the premise of public welfare as the highest value orientation, reconcile differences and avoid conflicts; coordinate and integrate on the basis of respect for differences, in order to achieve a conception of harmony and peace. Adhere to the "coordination with the same idea", promote the negotiation and communication between countries. China's excellent traditional culture reflects the ideology of fraternity, peace and common prosperity. It will play an important guiding role in the construction of the "One Belt And One Road" will inject new kinetic energy into the rapid growth of the global economy and bring greater well-being to the global people.

"One Belt And One Road" promotes the development of Chinese excellent traditional culture. From the perspective of time, the "One Belt And One Road" construction is an initiative that integrates ancient and modern cultures and has the profound historical heritage and cultural heritage. Traditional culture is the foundation and source of the development of modern culture. The history of the rise and fall of the ancient Silk Road has given us many useful lessons. To implement the "One Belt And One Road", we must protect the existing "Silk Road" cultural heritage through cultural inheritance and restoration. Through vigorous innovation, we will give new meaning to some ancient cultural landmarks and add new cultural charm. The "Silk Road" has become a cultural belt rich in cultural exchanges in the history of human, and has become a bridge for communication between the East and the West. It is necessary to give full play to the pioneering role of the "soft power" of the "Silk Road" traditional culture and promote the intertwined and organic interaction between China and other different civilizations. Focusing on the construction of the "One Belt And One Road", we will take advantage of the profound cultural heritage, the opening of cultural resources and the tolerance of cultural environment. Through assistance and cooperation, we will realize the mutual assistance and mutual construction and sharing of cultural resources in the wider space, and let the traditional culture rich in the value of the time. Glowing more vigorous vitality, promoting the recognition of Chinese traditional culture by people of all countries, thus achieving the commonwealth of the people.

\section{Role of English Teaching Integration into Chinese Excellent Traditional Culture}

The integration of English teaching into Chinese excellent traditional culture plays an important role, which is highlighted in the following three aspects:

(1) To promote and inherit Chinese traditional culture. The Chinese traditional culture has a long history. It has an endless vitality. The integration of Chinese excellent traditional culture in the process of English teaching can make the traditional culture better promoted and passed down. Carrying forward and inheriting Chinese traditional culture, transforming the high-quality resources 
contained in traditional culture into the soft power of cultural development is not only an important topic that the cultural world needs to explore and practice, but also the obligation and responsibility that English educators should take on.

(2) To enhance the patriotic enthusiasm and national pride of university students. If foreign language education overemphasizes Western culture and neglects Chinese excellent culture, it will inevitably lead to the loss of national self-confidence and thus the spread of Western culture. Foreign language teaching integrates into Chinese excellent traditional culture, realizes mutual penetration of two cultures, compares Chinese and foreign cultures, enables students to comprehend the essence of Chinese excellent traditional culture, enhances their patriotic enthusiasm and national self-esteem, thus promoting the promotion and inheritance of traditional culture.

(3) To improve the effectiveness of intercultural communication. Intercultural communication is a two-way activity. It is a kind of peer-to-peer interaction and communication. If only the Western culture is emphasized, and the traditional Chinese culture is neglected, it will lead to the unequal intercultural communication. Language learning is not only cultural knowledge and language skills, but also cultural inheritance. As the main force of the future development of the society, university students take on the heavy responsibility of Chinese cultural communication, strengthen the cultivation and promotion of traditional culture in English teaching, and contribute to the Chinese traditional excellent. The promotion and inheritance of culture will better realize intercultural exchanges.

\section{Reasons for the Absence of Chinese Excellent Traditional Culture in English Teaching}

The goal of English teaching is to develop students' linguistic and cultural abilities, so that students have "dual cultural ability" and "dual language ability". Therefore, English teaching is both language teaching and cultural teaching. However, subject to various conditions, the combination of language and culture has not penetrated into the teaching practice. The focus of English teaching is still on language teaching. The main reason for cultural teaching, especially the integration of Chinese traditional culture and English teaching, has not received sufficient attention. The main reasons including the following aspects:

(1) Lack of the recognition of Chinese excellent traditional culture. China's economy continues to develop, exchanges frequently with other countries, western culture flooded in, and people's lifestyles, values, and cultural conceptions has changed. Western culture with English as the carrier constantly baptizes the minds of young people, causing young people to feel confused about local culture and shift their eyes to western culture. The local culture is constantly being swallowed up by western culture. As a result, the phenomenon of Chinese traditional culture aphasia is serious.

(2) Lack of the sense of mission to Chinese excellent traditional cultural education. English and Chinese are the distinct representatives of the two cultures. From the perspective of China's current educational development, Chinese teaching is concentrated in the primary school to the university period. However, there are more Chinese classes in the university class hours than the English classes, and the emphasis degree on Chinese teaching is relatively low. English has the longest stay in all subjects. Students receive the corresponding degree through English tests. The degree of importance varies greatly and becomes an important reason for the lack of excellent traditional Chinese culture.

(3) The strong attack from the foreign culture. English is the language most used in international exchanges. It plays a positive role in international cultural exchanges and promotes the export and monopoly of western culture. The strong Western culture has had a tremendous attack on the culture of other countries, especially in the trend of economic globalization. English strongly hit, under the great attack of western culture, which poses a great threat to Chinese excellent traditional culture and reduces the competitiveness of Chinese excellent traditional culture. 


\section{Countermeasures on English Teaching Integration into Chinese Excellent Traditional Culture under the Background of "Belt and Road"}

The position of cultural teaching in foreign language teaching and the relationship between language teaching and cultural teaching are important topics in the field of foreign language teaching in the past century. More and more foreign language educators recognize the culture associated with the foreign language they are learning. It should become an important part of foreign language teaching. Integrating cultural teaching into foreign language teaching has become the consensus of many scholars and foreign language teachers. With the construction of "One Belt And One Road", cultural advancement can not only play an active role in promoting regional economic and trade cooperation along the line, but also play an important role in the cohesiveness and attractiveness of different regions and different ethnic groups. In view of the current situation of English culture teaching, the countermeasures for incorporating Chinese excellent traditional culture in the process of English teaching proposed in this paper are as follows:

(1) Let students feel the charm of Chinese excellent traditional culture. The Chinese civilization is the only great civilization in the world's ancient civilization that has not been interrupted and passed down today. China, with 5,000 years civilization has raised Chinese outstanding traditional culture and is the deepest spiritual pursuit of the Chinese. Higher education takes on the important functions and historical mission of cultural inheritance and innovation, allowing university students to absorb the ideological essence and moral essence of Chinese excellent traditional culture, and insists on integrating Chinese excellent traditional culture into university English teaching. This is not only the intrinsic requirement of strengthening cultural self-confidence and enhancing cultural consciousness. The requirements are also the mission of promoting the building of the cultural power, strengthening the Chinese soft power and international competitiveness. Let the essence of excellent traditional culture be internalized in the hearts of students and be seen in the behaviors of students.

(2) Let students fully understand the importance of the "One Belt And One Road" construction culture. The "One Belt And One Road" is not only an economic strategy but also a cultural strategy, and will inevitably reflect Chinese cultural characteristics, cultural consciousness and cultural self-confidence. First, the "One Belt And One Road" is a dual-core strategy for economic trade and cultural development. It deepens cultural exchanges and trades with countries along the line, promotes regional cooperation, enables countries along the route to absorb, integrates the rational content of foreign cultures and promotes commonality among different civilizations. Second, the "One Belt And One Road" has opened up channels for the integration and innovation of cultures in various countries. The "One Belt And One Road" is based on the integration of civilizations rather than the clash of civilizations. It is paving the way for economic exchanges and providing bridges for economic construction with value leadership and support.

(3) Cultivate students' correct Chinese and foreign cultural values. In the process of English teaching, teachers correctly guide students' thinking ways, deal with the relationship between Chinese traditional culture and western culture, and enhance the position of local culture in teaching. For foreign cultures, take the essence and discard the dregs, and absorb the excellent parts to develop Chinese traditional culture, instead of blind worship of western culture. In the process of teaching, students should be guided to understand the similarities and differences between the two cultures, so that students can form the correct way of thinking, deeply understand the relationship between western ideology and Chinese traditional local culture, enhance the influence of Chinese local culture on students' development, and handle the integration of English teaching process that the relationship between traditional culture and western culture.

(4) Cultivate students' intercultural communicative skills. Deeply understanding and mastering of traditional Chinese culture not only helps to maintain the self-confidence and dignity of individuals in intercultural communication, but also promotes the essence of Chinese culture, tells well the Chinese stories to the world, and spreads the good voice of China. In the construction of the "One Belt And One Road" talents warehouse, we must integrate cultural exchanges and cultivate 
"intercultural talents" who are proficient in Chinese and foreign cultures. While cultivating "foreign expert" that understand the language and culture of other countries, we must make it a "China expert". This requires increasing the traditional Chinese cultural content, including Chinese traditional culture lectures and contemporary cultural appreciation, in the process of cultivating foreign language talents, improving students' cultural quality and enhancing the sensitivity of cultural differences.

(5) Integrate excellent traditional culture into the English teaching content system. Inheriting and promoting Chinese traditional culture in English teaching requires re-adjusting the teaching content, integrating traditional culture into the English teaching content system, and scientifically arranging the teaching content. Strengthen the comparative study of Chinese traditional culture and western culture, understand the essence and heritage of Chinese traditional culture and western culture, and have the awareness of Chinese and western cultural communication and the spread of Chinese traditional culture. Teachers should give full play to the role of Chinese culture, educate students on the infiltration of Chinese traditional culture, and guide students to realize the external transmission of Chinese traditional culture in language practice. Students should also be guided through newspapers, movies, songs and network-related media resources to understand the profound connotations of Chinese excellent traditional culture.

(6) Integrate Chinese excellent traditional culture into English reading teaching. The rich cultural knowledge in reading materials is an important way to learn, understand and compare cultural differences. The process of reading an article is a process in which readers and authors communicate and collide in the spiritual world. Readers continuously acquire information, broaden their horizons, enhance attainment and enhance reading ability. A large number of articles provide readers with a real context for learning languages. In the reading teaching, we can gradually learn the traditional culture in English, including the poetry and songs with high level of translation, the traditional Chinese festivals, the heroes who love the people in the history, and the famous articles of the great rivers and mountains of the motherland, so as to broaden the culture of students' sight, resulting in respect for Chinese excellent traditional culture.

\section{Acknowledgement}

This work is supported by social science fund project of Liaoning province: Innovation Paths on Promote the Outstanding National Traditional Culture Going Out under the "One Belt And One Road" Construction (L18DMZ001); Westward Ecofeminism Literary Criticism and Its Reference and Innovation of Discourse Strategy (L16BWW001).

\section{References}

[1] J. S. Liao, "Analysis on the deficiency and countermeasures of Chinese traditional culture in college English teaching," Education Modernization, vol. 5, no. 12, pp. 167-168, 2018.

[2] Y. J. Che, "On the path of carrying forward traditional culture in higher vocational English teaching," Journal of Lanzhou Institute of Education, vol. 34, no. 4, pp. 134-135, 2018.

[3] T. Jiang, "On the lack of Chinese culture in English teaching and its countermeasures," http://www.fx361.com/page/2017/0103/478717.shtml, 2018-7-5.

[4] Q. Q. Lv, "Chinese excellent traditional culture should be integrated into the construction of 'One Belt And One Road'," http://www.lwlm.com/chuantongwenhua/201611/827483.htm, 2018-7-5.

[5] Y. Yi, "Lack of traditional culture in English teaching and its countermeasures," http://www.Xwlunwen.com/yingyulunwen/51176.html, 2018-4-9.

[6] H. Zhao, Y. Y. Zhang, X. Wang, "Problems and strategies of integrating traditional Chinese culture into college English teaching," Overseas English, vol. 19, no. 5, pp. 86-87, 2018.

[7] Y. Li, "The Inheritance and Promotion of 'Belt and Road' to the Excellent Chinese," Chongqing Social Sciences, vol. 15, no. 4, pp. 115-121, 2018. 